\title{
A Way towards Economic Growth in Pakistan: Role of Worker's Remittances Revisited
}

\author{
Hina Ali ${ }^{1}$, Saba Tahir ${ }^{2}$ \\ ${ }^{1}$ Assistant Professor, Department of Economics, The Women University Multan, Pakistan \\ Email: hinaali@wum.edu.pk \\ ${ }^{2}$ M. Sc. Scholar, Department of Economics, The Women University Multan, Pakistan
}

\begin{abstract}
This research is directed to study the role of remittances in the economic growth of Pakistan. In Pakistan workers, remittances are considered a second-largest source of finance after FDI. In this study, the relationship between worker's remittances and economic development in Pakistan is estimated by using the Ordinary Least Square (OLS) technique. Data is taken in time series for the period of 37 years from 1976 to 2013 from World Bank, economic surveys, and Stat bank of Pakistan. This research showed that worker's remittances are positive as well as significant with GDP growth and also playing a dynamic part in the economy of Pakistan. Savings (SAV) and Foreign direct investment (FDI) have positive and significant impacts on economic development. Therefore, the study recommends that there should be a proper setup that will help to attract more workers remittances into the economy. There is a need for such an official financial sector that inspires recipients to invest their savings into a productive sector that would result in economic growth.
\end{abstract}

Keywords: Economic Growth, Worker's Remittances, Gross Domestic Product, Foreign Direct Investment

\section{Introduction}

Worker's remittances are a transfer of money by foreign workers to an individual in their home country. Worker remittance is an exchange of money by labor in another country to an individual in his or her home country. There are many sources of cash inflow to a country but for developing countries, worker's remittances are the largest cash inflows. For the countries exporting labor to other countries, foreign remittances are a major part of international cash inflows. Worker's remittances are a noteworthy piece of global capital flows, particularly concerning work labor-export nations. Remittance is fundamentally 
foreign exchange that is transmitted by individuals who are living in a foreign country to their particular nations.

Workers' Remittances are a major source of foreign investment after Foreign Direct Investment (FDI). Worker's remittances are the most established source of foreign cash inflow in developing countries as compared to foreign debt, foreign aid, and FDI (Rahman, 2014). The role of worker's remittance in the financial improvement of receiving countries is thought to be a crucial region of study. Remittances have turned into an essential wellspring of foreign trade profit, dominatingly from the countries which are developed to the countries which are developing. The availability of outside trade by workers remittances helps the home countries in attaining a reasonably high economic growth by sinking the current account deficit; it has additionally reduced outside trade and besides outer debt burden. On the other hand workers, remittances may have a negative outcome on yield in home countries. Some studies also showed that the export of significant labor force decreases work power collaboration and work endeavors, which brings down yield (Dilshad, 2013).

There are four types' remittances: (a) one is Potential Remittances; which are a measure of the funds from the aggregate earnings of the workers living in a foreign country. (b)Second is Fixed Remittances; which is the fixed amount of cash sent to his family to meet the needs of the family. (c) Discretionary Remittances; which is the surplus amount of fixed remittances send to home countries. (d) Fourth is saved Remittances; demonstrated the amount difference between expected workers remittances and the number of remittances transferred to the home nation within the specific period. Whenever a laborer can accumulate and transmit them (Iqbal et. al., 2013).

The worker's remittance in Pakistan kept on being a critical part of the balance of payments have made a remarkable contribution towards generally foreign trade profit of the nation. The inflow of worker's remittance in Pakistan was broadly unstable over the long haul. The amount of remittance in Pakistan reached at $\$ 2.87$ billion in 1982 to 1983 . After 1982 to 1983 worker's remittances in Pakistan began unstably. Worker's remittances reached $\$ 1.85$ billion in 1991 and $\$ 1.41$ billion in 1997. On the other hand, foreign remittances again slightly rise to $\$ 1.48$ billion in 1998 and decrease to $\$ 0.98$ billion in 2000 . During the time of 2002 to 2003, the volume of workers remittances reaches $\$ 4.24$ billion and then again decreased to $\$ 3.86$ billion in 2004 (SBP, 2004). 
Remittances have assumed an urgent part in the development of Pakistan's economics during the past 10 years. Remittances coursed from not exactly $\$ 1.0$ billion to practically $\$ 8.0$ billion amid this period. Except for 2006 to 2007, remittances have dependably been greater than the FDI; these were nearly ten times of the formal improvement help that Pakistan got in the last 10 years; and without remittances, the present record discrepancy would be over $\$ 20$ billion in 2007 to 2008 and $\$ 16.4$ billion in 2008 to 2009 - touching off a genuine balance of payment calamity. Accordingly, remittances have assumed a dynamic part in not just averting balance of payment calamity additionally helping the state construct foreign exchange reserves. The objectives of this study are to investigate the main economic determining factors in Pakistan of worker's remittances. The specific goals involved in the research study are (1) Pay attention to the economic determining factors of foreign migration in Pakistan, (2) to find the correlation between foreign remittances and economic development and to evaluate the different forms of foreign remittances in Pakistan since the year 1970.

\section{Literature Review}

Buch, C., and Kuckulenz,(2004) examined the foreign remittances and money flow to developing countries. In this study data of the past three decades of big cross-section, countries were taken. The variables used in this study were a little bit odd, like the determinants of worker's remittances, foreign remittances as one type of money flow to developing countries, and the determinants of worker's remittances to those of private and official monetary flows. The study concluded that worker's remittances positively related to monetary flows to developing countries.

Ahmad, Hussain, and Sial (2005). conducted a study to identify the financial factors of international remittances in Pakistan. Data collected for the period of the year 1973 to 2005 to identify the economic determinants of remittances in Pakistan. Different variables like remittances in (US \$Million), gross domestic product (GDP) at constant factor price, a growth rate of the country, exchange rate Rs $\$$, unemployment rate, literacy percentage, spread degree of banks in Pakistan, unskilled worker's daily wage at Lahore, inflation and migrants went to overseas from Pakistan annually. The data for variables were collected from different sources. The latest techniques of error correction mechanism and co-integration were used in this study. The resulted figures of worker's remittances over the period described the worth of remittances in Pakistan. The results of the study showed that real worker's remittances in Pakistan have a positive relationship with the real gross domestic product (GDP), 
unemployment, and real development and negatively related to literacy, real income, and the spread of banks in Pakistan.

Zaman and Imrani (2005) had generally found the satisfactory results of worker remittances and import demand in Pakistan. In this paper quarterly data was used for the period 1975 to 2004. Total imports, domestic income, remittances, relative prices, intermediate goods imports, consumer goods imports, and capital goods imports were taken as variables in the paper. Augmented Dickey-Fuller (ADF), OLS, and Phillip-Person were used to estimate the relationship between remittances and import demand. The result conducted that remittances had no influence on the demand for imported consumer goods and remittances had a positive effect on raw materials and capital goods. Siddiqui and Kemal, A. R. (2006) examined the effect of two shocks, that a fall in worker's remittances from abroad and trade liberalization on poverty in Pakistan. They used the CGI framework and set consistent data for the year 1989 to 1990 . The result concluded that a positive effect of trade liberalization confirmed a negative outcome of the fall in foreign remittances in Pakistan.

Shafqat, Ahmad, and Bano, S. (2007) examined remittances as a determinant of consumption function in Pakistan. This study was conducted to find out the nexus between foreign remittances and consumption. Disposable income, Private consumption, and worker's remittances were used as variables in this study. By using the Ordinary Least Square (OLS) technique a model named a simple regression model was assessed. The study showed that there is a positive correlation between income and consumption and worker's remittances have large impacts on private consumption in the economy.

Rukhsana and Shahbaz (2008) conducted the relationship between remittances and poverty. Fully Modified Ordinary Least Square (FMOL) method was used in the research for the period 1973 to 2006. Remittances, inflation, trade openness, urbanization, GDP growth, and tax rate were the variables of this research. It was analyzed that remittances brought a decline in poverty.

Ahmad et al., (2010) examines the study on remittances and household welfare in Pakistan. They were used micro econometric analysis and General equilibrium framework for the period 2005-2006. In the paper human capital, regional characteristics, household characteristics, and wealth characteristics were taken as variables. The results showed that a decline in remittances will reduce the household's welfare and an increase in poverty. 
Pakistan Journal of Humanities and Social Sciences, 5(1), 2017

Yasmeen et al., (2011) analyzed how worker's remittances have impacts on the major two sectors of Pakistan. These sectors were total consumption of private investment in Pakistan. Data in Time series for the period of 1984 to 2009 was collected from economic surveys conducted over the years. To analyze the data OLS (ordinary least square) regression model had been used. The variables used in this study were GDP Private Investment, total consumption, and foreign remittances. The study had been concluded that remittances positively impacting on investment and consumption because of the economy and GDP growth with the increase in worker's remittances in Pakistan.

Javid, Arif, and Qayyum (2012) studied the influence of remittances on poverty and economic development in Pakistan. Through Autoregressive Distributed Lag (ARDL) technique data of Pakistan for the period, 1973 to 2011 was analyzed. The study pinpoints the connection between a reduction in poverty and economic growth. The different variables were taken like an investment, reduction in current account deficit, aggregate consumption; improve skills of people, and external debt burden. The dependent and explanatory of both variables were used in the study. The study showed that worker's remittance has a positive impact on the economy of Pakistan. With the increase of foreign remittances, the economy of Pakistan is growing.

Ukeje et, al, (2013) conducted a study to identify the impacts of worker's remittances on the economic growth of the Caribbean Region and Latin America. To examine that impact the variables taken were bank credit, ratios of bank deposits, quasi money to GDP, and ratios of bank deposits. Time series data for the period of 1991 to 2010 of 29 different states of the Caribbean region and Latin America was selected. The study used panel data techniques to investigate the impact of worker's remittances on economic development. By applying a Hausman test one technique was selected. The findings of the study showed the positive and significant impact of worker's remittances on economic development.

Hussain and Anjum (2014) analyzed the relationship between GDP growth and foreign remittances in Pakistan. They took time-series data from 1973 to 2011 to identify, what kind of relationship exists between remittances and economic growth. To control the problem of indigeneity, the method used was the Generalized method of moments (GMM). The variables taken in this study were world GDP growth, Exchange rate, terms of trade (TOT), government spending, trade openness, economic development, and inflation. The 
findings of the study were that foreign remittances affected the GDP growth positively and also significantly in Pakistan.

\section{Theoretical Framework - Neo-Classical Theory of Migration}

The Neo-classical theory of migration informed the explanations behind migration; as indicated by this theory these reasons may be economic. A single migrant attempted to boost his efficacy level and this level was resolved after he decided to migrate. In this contention, the government of a domestic country is encouraged to permit the individuals for migration with the goal that market strengths might accomplish the required level of stability in the economy (Borjas and Miller, 2003).

The microeconomic and macroeconomic variables depicted the course of migration from one nation to another nation as indicated by this hypothesis of migration. An individual's choice to migrate at a microeconomic level based upon the evaluation of profit from cost analysis (Sjaastad 1962, Todaro 1976).If the net consequence of the analysis of cost-benefit was positive then analysis pronounced the choice for migration. The imperative variables were the wage disparities and the employment rate among the nation of origin and host nation that have to be considered.

\section{Data Collection}

This research has been carried out to recognize the contribution of worker's remittance to economic growth. Time series data from 1976 to 2013 have been collected from The World Bank and Handbook of Statistics of the Pakistan economy and examined through the regression model. As the dependent variable Gross domestic product (GDP) has been taken and as independent variables worker's remittances (WR) foreign direct investment (FDI) and savings (SAV) has been taken. The results showed that there exists a positive relationship between the worker's remittances and economic growth.

The quantitative variables are used in the estimation of the relationship between economic growth and workers' remittances are follows in the table 1 . The table 1 shows all the variables used in this research. This table also shows the units of measurement and expected signs of the variables. Here dependent variable is a gross domestic product (GDP) which has expected positive significant sign. And independent variables are workers' remittances (WR), foreign direct investment (FDI) which also has a positive significant impact and savings (SAV) which may be a negative or positive significant impact. 
Pakistan Journal of Humanities and Social Sciences, 5(1), 2017

Table 1: Variables descriptions and their relationships

\begin{tabular}{|c|c|c|c|}
\hline Variables & Description of variables & Units of measurement & Expected sign \\
\hline \multicolumn{4}{|c|}{ Dependent variable } \\
\hline GDP & Gross Domestic Product & $\begin{array}{c}\text { In current billions of US } \\
\text { dollars }\end{array}$ & + ve sign \\
& \multicolumn{3}{|c|}{ Independent variables } \\
\hline WR & Workers' Remittances & $\begin{array}{c}\text { In current million US } \\
\text { dollars }\end{array}$ & + ve sign \\
\hline FDI & Foreign Direct Investment & $\begin{array}{c}\text { In current billions of US } \\
\text { dollars }\end{array}$ & + ve sign \\
\hline SAV & Savings & $\begin{array}{c}\text { In current billions of US } \\
\text { dollars }\end{array}$ & $+/$-ve sign \\
\hline
\end{tabular}

Source: Author's Calculation

Figure 1: Relationship of GDP and Worker's Remittances

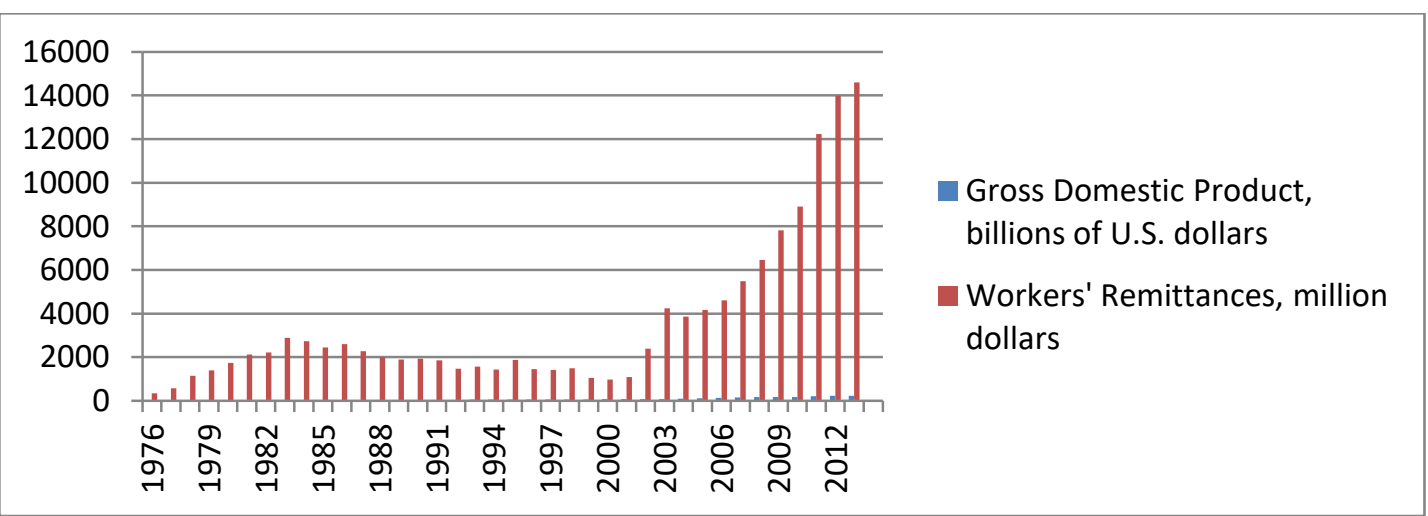

Source: Author's calculation

The above figure shows a positively significant trend, the red line shows workers' remittances which is increasing with time and the blue line shows GDP growth rate which is dependent on workers' remittances, with the increase in workers' remittances GDP growth rate also increases. The higher value of workers' remittances received in the year 2013 which was 14595 and lower value received in the year 1976 which was 339. Similarly, the GDP growth rate is higher in the year 2013 which was 232.29 and lower in the year 1976 which was 13.34 . 
Figure 2: Relationship of GDP and Savings

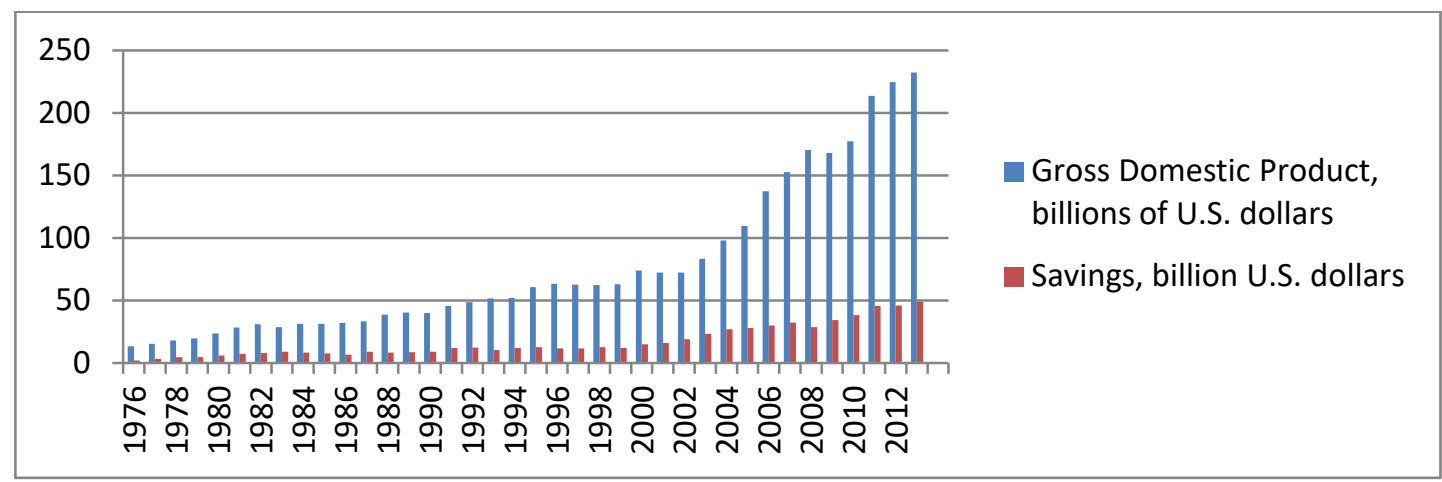

Source: Author's calculation (MS Excel)

The above figure 2 shows the positively significant trend, GDP shows by blue lines which are taken in billions of U.S. dollars while red lines show the growth rate of savings. Both are increasing trends with the time, GDP growth rate is dependent on savings growth rate which is the independent variable. When the savings rate increases, GDP also increases. GDP growth rate in the year 1976 was 13.34 which is the lower amount in all taken years and the saving rate in that year was1.96 which is also very low. In 2000 GDP was 73.95 and saving was 15.05 . In the year 2012 GDP was 224.38 and saving was 46.01 which is a higher amount of all years.

\section{Figure 3: Relationship of GDP and Foreign Direct Investment}

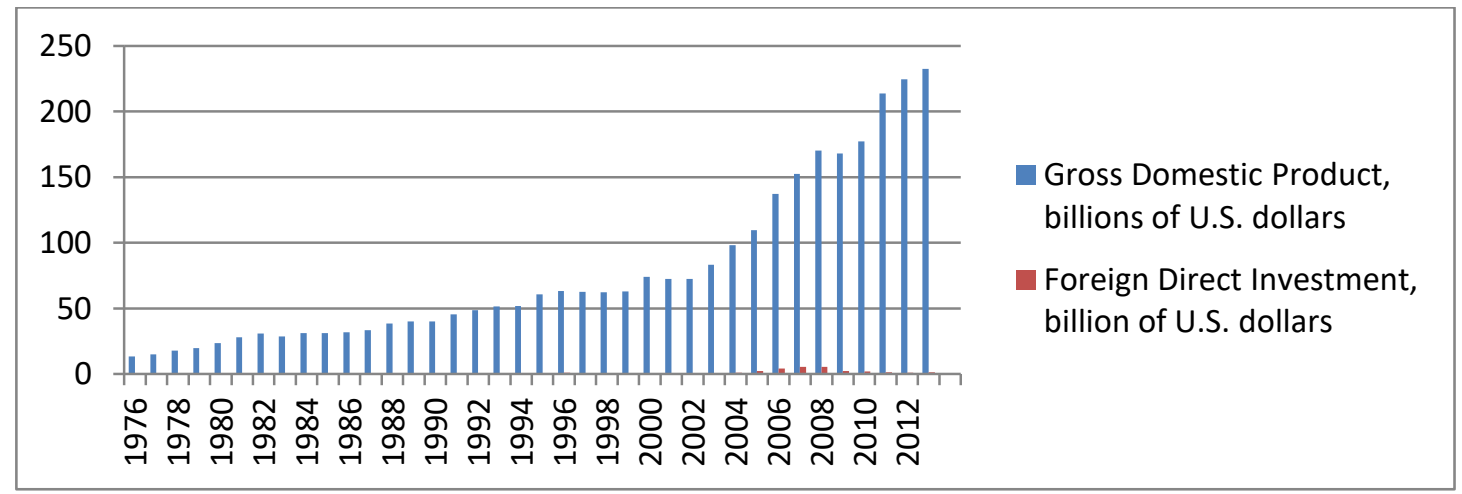

Source: Author's calculation (MS Excel)

The figure 3 shows the relationship between GDP and FDI. After FDI, worker's remittance is the major source of foreign investment. The very small increase in FDI gives a very high increase in GDP. In 1976 GDP was 13.34 while FDI was 0.01 which is the minimum value of the taken years and in the year 1995 GDP was 60.64 while FDI was 0.72 . 
In the year 2012 GDP growth was 224.38 and FDI was 0.86 which is the highest amount. This shows that the GDP growth rate is dependent on worker's remittances, savings, and FDI. With the increase of the amount of these variables economic growth also increases.

\section{Methodology}

The OLS method is used to measure the relationship between the dependent and independent variables in the regression analysis. In the regression analysis, the most popular and widely used is OLS. The method was developed by Cart Friedrich Gauses (1821).

\section{A. Model Specification}

In the regression analysis the model is used as follows:

$$
\mathrm{Y}=\mathrm{a} 0+\mathrm{b} 1 \mathrm{X} 1+\mathrm{b} 2 \mathrm{X} 2+\mathrm{b} 3 \mathrm{X} 3+\mathrm{e}
$$

In this model:

$\mathrm{Y}=$ dependent variable

$\mathrm{X} 1, \mathrm{X} 2, \mathrm{X} 3$ are independent variables. In this study the model that shows the relationship between workers' remittances and economic growth is discussed below:

$\begin{array}{lll} & \mathrm{Y}(\mathrm{GDP})=\mathrm{a} 0+\mathrm{b} 1(\mathrm{WR})+\mathrm{b} 2(\mathrm{FDI})+\mathrm{b} 3(\mathrm{SAV})+\mathrm{e} \\ \mathrm{GDP} & =\text { Gross Domestic Product } \\ \mathrm{WR}= & \text { Worker's Remittances } \\ \mathrm{FDI} & = & \text { Foreign Direct Investment } \\ \mathrm{SAV} & = & \text { Saving } \\ \mathrm{e} & = & \text { error term }\end{array}$

\section{Analysis and Results}

The table 2 shows the descriptive statistics of all the variables included in the study. We can see the average of worker's remittance that is 3493.93 , the maximum and minimum value of remittances during the studied years that ismaximum14595 in 2013 and minimum 339 in 1976, the standard deviation of worker's remittance during the studied years 3556.729, kurtosis of workers' remittances during the studied year's 6.050526 which shows that the variables are leptokurtic, the bark-beta test of normality shows combined results skewness and kurtosis, the computed probability value of workers' remittances and foreign direct investment is 0 which is not normally distributed and all other variables are normally distributed and other correlated descriptive statistics that have been collected by the results of the estimation. 
Table 2: Descriptive Statistics

\begin{tabular}{|l|l|l|l|l|}
\hline & GDP & WR & FDI & SAV \\
\hline Mean & 76.75605 & 3493.93 & 0.913947 & 16.81816 \\
\hline Median & 56.265 & 2064.265 & 0.365 & 11.755 \\
\hline Maximum & 232.29 & 14595 & 5.59 & 48.86 \\
\hline Minimum & 13.34 & 339 & 0.01 & 1.96 \\
\hline Std. Dev. & 62.22036 & 3556.729 & 1.389856 & 12.8481 \\
\hline Skewness & 1.23412 & 1.981706 & 2.342234 & 1.132829 \\
\hline Kurtosis & 3.344486 & 6.050526 & 7.741635 & 3.155679 \\
\hline Jarque-Bera & 9.83389 & 39.60605 & 70.3433 & 8.165945 \\
\hline Probability & 0.007321 & 0 & 0 & 0.016857 \\
\hline Sum & 2916.73 & 132769.3 & 34.73 & 639.09 \\
\hline Sum Sq. Dev. & 143240.8 & $4.68 \mathrm{E}+08$ & 71.47291 & 6107.73 \\
\hline
\end{tabular}

The table 3 shows the correlation matrix which showed the relationship between all variables with each other included in this study. The relationship between savings and economic growth (GDP and SAV) is 0.984 which shows a strong positive relationship. The relationship of foreign direct investment and economic growth (GDP and FDI) is 0.643 which also shows positive relationships though the relationship of economic growth with workers' remittances (GDP with WR) is 0.921 which shows a strong positive relationship.

Table 3: Correlation matrix

\begin{tabular}{|l|l|l|l|l|}
\hline & GDP & WR & FDI & SAV \\
\hline GDP & 1 & & & \\
\hline WR & 0.9214 & 1 & & \\
\hline FDI & 0.6434 & 0.4163 & 1 & \\
\hline SAV & 0.9849 & 0.9199 & 0.6030 & 1 \\
\hline
\end{tabular}

Source: Author's calculation

The results of the regression model have been shown in the above table 4 . This shows that the model is best fit by way of the R-square is 0.979 and adjusted R-square is 0.977 which is near 1 ; it shows that there is severe multicollinearity between variables. The probability of worker's remittances is 0.0047 and the t-statistics shows the positive amount 
Pakistan Journal of Humanities and Social Sciences, 5(1), 2017

which is greater than two that is 3.025 so we can easily determine that worker's remittances have a significant positive relationship with economic growth (GDP).

Table 4: Results of the regression model

\begin{tabular}{|l|l|l|l|l|}
\hline Variable & Coefficient & Std. Error & t-Statistic & Prob. \\
\hline C & 0.462373 & 2.740342 & 0.168728 & 0.8670 \\
\hline WR & 0.003695 & 0.001221 & 3.025763 & 0.0047 \\
\hline SAV & 5.533605 & 1.535569 & 3.603620 & 0.0010 \\
\hline R-squared & 3.468126 & 0.385276 & 9.001676 & 0.0000 \\
\hline Adjusted R-squared & 0.979535 & Mean dependent var & 76.75605 \\
\hline S.E. of regression & 0.977729 & S.D. dependent var & 62.22036 \\
\hline Sum squared resid & 9.285384 & Akaike info criterion & 7.394061 \\
\hline Log-likelihood & 2931.424 & Schwarz criterion & 7.566438 \\
\hline F-statistic & -136.4872 & Hannan-Quinn criteria. & 7.455391 \\
\hline Prob(F-statistic) & 542.4574 & Durbin-Watson stat & 0.651230 \\
\hline
\end{tabular}

Source: Author's calculation (Eviews 7.0)

\section{Conclusion and Policy Recommendations}

\section{A. Conclusion}

Worker's remittances have an important part in developing countries. After FDI it is the largest source of financial influx. With time the importance of worker's remittances increases in the receiver countries. Among the countries receiving remittances, Pakistan ranks 7. Remittance has a progressive effect on the economy of Pakistan. Our major goal of the study which we have to elaborate is that the remittances are beneficial for the economy of Pakistan. In this research, we investigate the part played by workers' remittances in the economic development of Pakistan for the period 1976 to 2013 through the empirical regression model and it is recognized that worker's remittances and economic development are related to each other positively in Pakistan. The result declared that workers' remittances are considerably related to savings. The workers' remittances are also positively related to GDP. The relationship between FDI and worker's remittances is also positively significant. Our result shows that workers' remittances are positively related to the GDP growth rate from 1976 to 2013. This result recommends that the right strategies can produce a way for the 
remittances to flow into useful investment accomplishments in the future. If the worker remittances were not there, probably the exchange rate, monetary and fiscal policies would be pressurized a lot.

\section{B. Policy Recommendations}

Some suggestions derived from our research are as follows:

- Pakistan should take advantage of the influxes of the workers' remittance effectively for economic growth and development.

- Pakistan ought to focus on these workers' remittance that these are beneficial for economic development; additionally, these workers' remittance is decreasing poverty also.

- The worker remittances are an important source of external interchange and help to minimize the difficulty of equilibrium of expense.

- If those workers remittance is used efficiently as a beneficial part those can help in beating the issue of mind channel and migration and the successful use of those remittances can help in accomplishing maintainable development.

- To support the remitters about the advantages of remittances new sensible strategies required to be planned.

- As an approach matter, the govt. should give interesting investment chances to pull more remittances inflows.

- The government also desires to determine more marketplaces for manpower trades to get maintainable remittances.

- Therefore, there is a necessity to find methods to support remittances and raise their advantageous procedure. 
Pakistan Journal of Humanities and Social Sciences, 5(1), 2017

\section{References}

Abbas, K., Muhammad Sabir, H., Shehzadi, A., and Abbas, Q. (2014). Impact of Workers' Remittances on Household Welfare in District Jhang (A Case Study of Tehsil 18 Hazari) Journal of Finance and Economics, 2014, Vol. 2, No. 4, 131-135.

Ahmad, N., Hussain, Z., and Sial, M. H. (2005). Economic Determinants of International Remittances in Pakistan. Editorial Advisory Board e, 18(1), 79-85.

Ahmed, V., Sugiyarto, G., and Jha, S. (2010). Remittances and Household Welfare: A Case Study of Pakistan. Asian Development Bank Economics Working Paper Series, (194).

Buch, C., and Kuckulenz,(2004) A. Worker Remittances and Capital Flow to Developing Countries. SSRN Journal, 04-31.

Dilshad, W. (2013). Impact of Workers' Remittances on Economic Growth: An Empirical Study of Pakistan's Economy. IJBM, 8(24).

Hussain, R., and Anjum, G. A. (2014).Worker's Remittances and GDP Growth in Pakistan. International Journal of Economics and Financial Issues, 4(2), 376-381.

Iqbal, J., Nosheen, M., \&Javed, A. (2013). The Nexus between Foreign Remittances and Inflation: Evidence from Pakistan. Pakistan Journal of Social Sciences (PJSS), 33(2), 331-342.

Iqbal, Z., and Sattar, A. (2010).The contribution of workers' remittances to economic growth in Pakistan. Working Papers \& Research Reports, RR-No.187.

Javid, M., Arif, U., and Qayyum, A. (2012).Impact of remittances on economic growth and poverty. Academic Research International Vol, 2

Kalim, R., and Shahbaz, M. (2009). Remittances and poverty nexus: Evidence from Pakistan. International Research Journal of Finance and Economics, 29, 46-59.

Khan, M., Rahim, T., Bakhtiar, Y., andNawab, B. (2007).Remittances as a determinant of consumption function empirical evidence from Pakistan).Sarhad Journal of Agriculture (Pakistan) Sarhad J. Agric. Vol. 23, No. 4, 2007.

Rahman, Z. U. (2014). Worker's Remittances and Economic Development in Pakistan A Time Series Analysis (1980-2010). Journal of Economics and Sustainable Development, 5(22), 51-54.

Shafqat, M. M., Ahmad, A., \&Bano, S. (2007). Impact of Worker Remittances on Economic Growth of Pakistan: Analysis of Pakistan's Economy. JOURNAL OF BUSINESS RESEARCH TURK, 6. 
Siddiqui, R., \& Kemal, A. R. (2006). Remittances, trade liberalization, and poverty in Pakistan: The role of excluded variables in poverty change analysis. The Pakistan Development Review, 383-415.

Ukeje, E. U., \&Obiechina, M. E. (2013). Workers' remittances-economic growth nexus: Evidence from Nigeria, using an error correction methodology. International Journal of Humanities and Social Science, 3(7), 212-227.

Yasmeen, K., Anjum, A., Yasmeen, K., \&Twakal, S. (2011). The Impact of Workers' Remittances on Private Investment and Total Consumption in Pakistan.Najafi, 1(1), 152.

Zaman, K. U., \&Imrani, N. A. (2010). Workers' remittances and import demand in Pakistan. Philippine Review of Economics, 42(2). 